PBN Maseko

University of the Free State

DOI: $h$ ttp://dx.doi.

org/10.18820/2519593X/pie. v35i2.14

ISSN 0258-2236

e-ISSN 2519-593X

Perspectives in Education

2017 35(2): 181-195

(C) UVIUFS

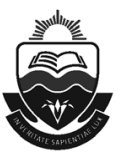

\section{Codification, meritocracy and performativity: Debilitating factors for black pre-service teachers}

\begin{abstract}
This article presents an argument and commentary about the concomitant effects of codification, meritocracy and performativity in the academic performance of a cohort of black African Foundation Phase Bachelor of Education degree students at a previously predominantly white institution of higher learning. The objective of this paper is to illustrate the point that the combination of codification, meritocracy and performativity has potentially debilitating ramifications for the performance of this cohort of pre-service teachers. In this instance, language is a codification mechanism and a means towards epistemological access. This paper posits the viewpoint that the sociocultural backgrounds of the cohort predispose them to the resultant negative effects of the combination of the three factors. The study that forms the basis of this article used the qualitative theoretical orientation of the transformative paradigm to pursue a critical emancipatory and transformative theoretical agenda. This agenda is embodied in the recommendations that are informed by an infusion of the literature, the participants' observations, as accrued from the data, and the researcher's reflections. The intention of this socialjustice-oriented support strategy is to make an implied decolonial contribution towards counteracting and diffusing the potentially debilitating effects of the combination of codification, meritocracy and performativity.
\end{abstract}

Keywords: pre-service teachers, codification, performativity, academic performance, language, epistemological access, transformative, emancipatory

\section{Introduction}

This paper is premised upon a study that was positioned to contribute to a transformative Department of Higher Education and Training (DHET) mandate to institutions of higher learning. The intention of the mandate was to strengthen and develop the B.Ed. Foundation Phase programme. With this in mind, the focus of the study was on the concomitant effects of the convergence of language and identity on the black African cohort of this programme. This article thus draws from a DHET-mandated study, as mentioned earlier, to make inferences about the effects of the combination of codification, meritocracy and performativity on a cohort of black B.Ed. Foundation Phase pre-service teachers. In this paper, language is highlighted, not only 
as a means towards epistemological access, but with its association with the combination of codification (Bernstein, 1990), meritocracy (Lister, 2006; McNamee \& Miller Jr, 2004) and performativity (Ball, 2003, 2012; McFarlane, 2013). In this regard, this paper is thus a reconceptualisation of language as part of the codification system of the academia.

The cohort under study is connoted as black first generation (G1) students, second language (L2) speakers of English and previously disadvantaged individuals (PDIs). "Black" is used to denote those who are of African descent and whose first language is a black South African language. Additional distinguishing features of the cohort are that they attended schools situated in areas that are categorised as urban (township), peri-urban (part urban and part rural) and rural (villages and farms). These are areas that were designated for black Africans under the apartheid rule (Bozalek et al., 2010). In this discussion, meritocracy and performativity feature because of the performance practices that often do not consider the diverse preparation (or inadequacy thereof) for the culture, language and, thus, codification system of the academia. The insights gleaned through the study are thus used to inform the stance of this discussion with regard to the significance of class-regulated prior exposure in relation to academic performance.

\section{Context of the discussion}

Bernstein (1990:13) observes that "class-regulated codes position subjects with respect to dominant and dominated forms of communication", adding that "ideology is constituted...in such positioning [where] class-regulated codes position subjects with respect to dominant forms of communication". The reference to codes, in connection with communication and with special reference to dominant forms of communication and positioning, is pertinent to this discussion. This is because language is a means of codification and communication, where English is the dominant form of communication within the context of the academia. The L2 pre-service teacher cohort is positioned as subjugated subjects with regard to the codification system. The word "class" in Bernstein's (1990) citation above relates to Bourdieu's (1991) conceptualisation of social standing or status, which also has implications for cultural capital and valued epistemic meaning-making systems. Cultural capital refers to the type of educational skills and knowledge bases that provide an advantage in achieving a particular standing, which, in this instance, is an academic standing that is compatible with the cultural capital of the academia.

The aforementioned implies a particular positioning of the L2 cohort, with ramifications for their performance as dominated subjects, based on their limited familiarity with the codification system of the academia. In this regard, Bernstein (1990) is of the view that class relations privilege certain forms of communication, which transmit what he refers to as "dominant and dominated codes". The concept of meritocracy (McNamee \& Miller Jr, 2004) comes into view because of the academic context where merit is regarded as part of the criteria for eligibility for academic success. Meritocracy is simplistically described through the meritocratic formula, IQ + effort $=$ success, as envisioned by Young (2006). The meritocratic view is that success is not determined by class, but by effort. In this discussion, this view is however critiqued based on the inequitable distribution of exposure founded on class privilege or non-privilege.

Lister's (2006) observation that meritocracy legitimises and increases inequality is in consonance with the stance of this paper. The assumption that can be made here is that privileged backgrounds imply prior exposure to codification and meritocratic advantage over 
those who have had limited exposure. This means, therefore, that those from less privileged backgrounds are usually found wanting within a system of performativity, as it is conceived of in this paper. Ball's $(2003,2012)$ conceptualisation of performativity is usually associated with the performance measures that are used to evaluate teacher/educator performance in teaching and learning environments. McFarlane (2013) correlates teacher performativity with student performativity by stating that they are mirror images of each other. Of significance here is that the context of the research site carries connotations of inequity. Within this context, prior exposure to the codification system has a bearing on performance, as it is conceived of in this study. Within the context of this discussion, "performance" refers primarily to the ability to participate freely and actively in class activities and discussions, while deriving the full pedagogical benefit. "Full benefit" also includes the ability to understand instructions adequately in order to respond appropriately to evaluative questions in a manner that will auger well for performance. The question of voice, voicelessness and power relations in reference to class participation (Mayes, 2010), is brought into oblique view here. In this regard, the participants of the study confirmed their inability to express themselves freely for fear of exposing themselves to ridicule. Some even explicitly pointed out that their trepidation resulted in failure to participate in class, even where there was a need to ask clarity-seeking questions.

\section{Theoretical and conceptual framework}

The appropriateness of the transformative paradigm (Mertens, 2009) hinges on its action and agency agenda to transform the lives of the participants and the institutions that fall under its lens of enquiry (Creswell, 2008; Mezirow, 2003). Mertens (2010:21) also presents the view that "no unified body of literature is representative of the transformative paradigms". This theory is conventionally associated with mixed-methods research (Mertens, 2005); however, its applicability to this study is viewed from a purely qualitative research paradigm (Padgett, 1998; Patton, 2002), with the view of contributing qualitatively towards transforming the lives of the participants, including that of the researcher (Creswell, 2003). The relevance for this study is that the participants (both lecturers and students) were viewed as co-researchers, whose views were valued as potential contributions towards the transformational agenda.

The critical emancipatory and transformative theoretical stance for this discussion is an appropriate vehicle for an agenda that aims at critiquing and giving commentary with the intention of transforming and empowering. In this regard, Ayers' (2004: 1) view that "teaching at its best is an enterprise that helps human beings to reach the full measure of their humanity", is an implicit echo of the study's critical and transformative thematic underpinnings. His view is closely connected to the critical emancipatory research theory (Mahlomaholo, 2009) with its concern to empower people and ensure that they attain an elevated status in life. Ayers' (2004) conceptualisation of teaching and transformative social justice finds resonance in the critical theory and critical pedagogy (Freire, 1970, 1995; Kincheloe, 2008; Kincheloe, McLaren \& Steinberg, 2007; Ledwith, 2007). Ledwith (2007) opines that critical pedagogy must engage with the politics of difference if it is to realise its transformative potential. She further points out the need for the situatedness of this ideology within a social justice agenda. The study's transformative and decolonial orientation necessitated the transformative learning theory lens with its tenets of, inter alia, reflectivity, inclusivity and promoting the voice of the historically and circumstantially silenced (Mezirow, 2000). This aligns with a decolonial agenda, which is based on criticality, that intends to draw attention to practices that perpetuate inequity, with the intention to counter them with contextually responsive practices. Within 
the context of the argument of this paper, it is worth noting that Gatsheni-Ndluvu (2015:23) conceives of the phenomenon of decoloniality as a "search for better ways of theorising and explaining the meaning of liberation and freedom as well as taking the struggles forward in contemporary conjecture".

In this discussion, decolonial theorising entails looking at language, as the currency of the academia and with specific reference to the L2 cohort through an emancipatory and transformative lens. Here attention is drawn to McFarlane's (2013) conceptualisation of performativity as presenteeism, learnerism and soul craft. Of significance to this discussion is that, according to him, presenteeism relates to the concern with class attendance, while learnerism measures performance in relation to the nature of class participation. Soul craft emphasises the students' dispositions and values. The conceptualisation of learnerism, as associated with class performance, bears specific relevance for this discussion. The conjecture made here, is that this practice results in severe discomfort, which ultimately has a bearing on academic performance. This paper argues that a transformative and emancipatory response is required in this regard.

\section{Research objective}

The main aim of this study was to contribute towards the improvement of the B.Ed. Foundation Phase programme by exploring the extent to which the convergence of language and identity bears relevance for the academic performance and portraiture of the black L2 student teacher cohort.

\section{Problem statement}

The problem that prompted the study upon which this paper is premised, presented the convergence of language (as related to codification) and identity - in its association with ontological development - as problematic in relation to the academic performance of black African FP B.Ed. pre-service teachers.

\section{Research question}

For the purposes of this discussion, attention is drawn only to the key research question: How does the convergence of language and identity affect the academic performance and influence the portraiture of Black L2 B.Ed. Foundation Phase students? This question was posed with the intention of looking at the interplay between the phenomena of language and identity in relation to performance, as they were conceived of in this study.

\section{Research design}

The choice of qualitative research as an overarching method of enquiry (Creswell, 2008) was appropriate for the study because of the provision it made for the interpretation of the data in alignment with an emancipatory transformative orientation. The interviews and narratives emanating from them served the purpose of allowing the research to assume an epistemological and ontological stance (Maseko, 2015).

\section{Methodology}

The data collection was conducted in compliance with ethical considerations and protocol within the qualitative research design (Creswell, 2008). A further consideration in the choice of 
participants was that the researchers designing qualitative studies should have clear criteria and rationales for their decisions. Within the paradigm of criticality, this also means that when sorting data, there should be reflectivity and cognisance of the underlying issues, such as the power relations (Mayes, 2010) that are often at play in these contexts (Bertram \& Christiansen, 2014). With the aforementioned in mind, one-on-one semi-structured open-ended interviews were used for their suitability with regard to the nature of the evidence that was sought, as well as the fact that they promoted a participatory approach (Denzin \& Lincoln, 2000). Some of the questions were adapted and modified to allow for this and to elicit data that would assist towards the generation of relevant data.

The semi-structured and open-ended interviews facilitated easier interaction and further provided insight into the interviewees' consciousness, while simultaneously providing access to non-verbal semiotic cues that can be gleaned only through observation during the interview (Gilham, 2000). In this regard, there were instances during which trepidation, as a semiotic cue of uneasiness, was visibly etched on some participants' faces to illustrate discomfiture. This methodology was further validated because, as Holstein and Gubrium (1995:76) note, "interviews are an appropriate instrument to engage the participant and designate the narrative terrain". The narrative element of the interview was tapped into to elicit stories and to create a portrait of the interviewees (Lawrence-Lightfoot, 2002). While the language of communication was primarily English, provision was also made for code switching as dictated by the participants' language preference and competence, as well as in consideration of the social justice agenda of the study.

The interviews were recorded and transcribed through multiple "listening moments" and interpretations (Creswell, 2003). The advantage of listening repeatedly to the recordings was that this facilitated familiarity with the voices of the participants, which was conducive to maintaining a real connection that extended beyond the interview sessions. The transcription process allowed for verbatim transcriptions. Verbatim utterances were formulated as a direct and credible representation of the participants' voices and experiences (Maseko, 2015). The transcriptions entailed an iterative process of reading and thinking. In order to ensure trustworthiness and validity (Creswell \& Miller, 2000), the transcriptions were read and reread.

\section{Analysis}

A textual analysis of the transcriptions was done, using the underpinnings of critical discourse analysis (Fairclough, 1992, 2003). Critical discourse analysis (CDA) was regarded as an appropriate deconstructive tool because it does ideological work, which addresses critical emancipatory concerns at a textual, discursive and social level (Fairclough \& Wodak, 1997; Van Dijk, 2008). The discursive semi-structured interviews yielded transcriptions that facilitated textual analysis that reflected social relations - in this case, the ramifications of communicative practices within the codified and meritocratic classroom contexts of the academia. Three themes were deductively derived and then inductively linked to categories (Bertram \& Christiansen, 2014). For the purposes of this discussion, however, the focus will primarily be on the two themes and associated categories that relate to language use and, thus, codification and, by extension, meritocracy and performativity.

The extent to which the participants were able to engage in class activities was gleaned from their interview narratives as a reflection of their lived experiences (Akinbode, 2013). The transformative paradigm and its associated approaches were used to interpret the 
students' ability to participate actively and meaningfully in classroom settings. This reflected a need for support that would facilitate appropriate counter-hegemonic deconstruction of the situational contexts.

\section{Ethical considerations}

Ethical considerations were taken into account and complied with in consideration of the institution's ethics clearance requirements. Letters of invitation were sent to the participants of the study. The participants were assured of confidentiality and anonymity. Consent was sought from the Head of Department and Dean to conduct the research with students from the Early Childhood Education (ECE) Department and the Faculty of Education of the institution.

\section{Selection of participants}

The student participants were selected based on their availability and compatibility with the criteria (as listed below). There were two levels of participants, namely students and lecturers. The first and main participant group comprised nine participants, that is, $n=9$ ( $n=3$ in the $1^{\text {st }}$ year, $n=3$ in the $2^{\text {nd }}$ year and $n=3$ in the $3^{\text {rd }}$ year) students from the pre-service teacher cohort. Pseudonyms were used to categorise the participants in a manner that would distinguish their level of study and position in the sequence of interviews. For example, the first student in that category was given the pseudonym "Y1s1" (Maseko, 2015).

\section{Criteria for participants}

\section{Student participants}

Below are the criteria that informed the choice of student participants:

- Black African B.Ed. Foundation Phase students

- L2 speakers of English with one (or more) of the nine black South African languages as a home language/mother tongue

- Classified as PDI

- From a pre-university school education, they should have been in a school specifically designated for PDIs and situated in an urban, peri-urban or rural area

- First-generation university students

\section{Lecturers}

The second layer of participants, that is, the lecturers, was chosen based on the following criteria:

- Their availability to participate in their capacity as B.Ed. Foundation Phase lecturers

- They could provide both sides of the story of language and identity based on language and identity (as informed by their race) and the implications of these phenomena, taking into account the various factors that play a role in this.

- Their appropriateness (as lecturers of the cohort) and their willingness to make themselves available as participants 


\section{Interview questions}

There were two sets of interview schedules with ten items for the student participants and five for the lecturer participants (Maseko, 2015:90-91).

\section{Interview schedule: Students}

\begin{tabular}{|c|l|}
\hline 1 & $\begin{array}{l}\text { Discuss the extent to which English was used as a medium of instruction at the schools you } \\
\text { attended before you came to the university. }\end{array}$ \\
\hline 2 & $\begin{array}{l}\text { Briefly discuss your experience with the English language and your exposure to it within the } \\
\text { pre-university contexts. }\end{array}$ \\
\hline 3 & $\begin{array}{l}\text { Describe your experience with regard to the use of English as a medium of instruction as a } \\
\text { B.Ed. Foundation Phase student. }\end{array}$ \\
\hline 4 & $\begin{array}{l}\text { How do you feel about expressing yourself verbally in English in a classroom/lecture } \\
\text { hall setting? }\end{array}$ \\
\hline 5. & $\begin{array}{l}\text { Are you able to clearly understand the lecturer and follow the proceedings during } \\
\text { lecture sessions? }\end{array}$ \\
\hline 6 & $\begin{array}{l}\text { How do you feel about expressing yourself in writing in English during tests } \\
\text { and assignments? }\end{array}$ \\
\hline 7 & $\begin{array}{l}\text { Are the instructions during tests and assignments written in a manner that you can } \\
\text { easily understand? }\end{array}$ \\
\hline 8 & $\begin{array}{l}\text { Are you confident about your ability to respond appropriately to the requirement of } \\
\text { given tasks? }\end{array}$ \\
\hline 9 & $\begin{array}{l}\text { Discuss whether you think that it would be to your advantage to undertake your B.Ed. } \\
\text { Foundation Phase studies in your Home Language. }\end{array}$ \\
\hline 10 & $\begin{array}{l}\text { Do you have any suggestions regarding how you can be assisted to cope with any language- } \\
\text { related challenges you might be facing as a B.Ed. Foundation Phase university student? }\end{array}$ \\
\hline
\end{tabular}




\section{Interview schedule: Lecturers}

\begin{tabular}{|c|c|}
\hline 1 & $\begin{array}{l}\text { Comment on the performance (as it is conceived of in this study) of Black L2 speakers of } \\
\text { English in your classes. }\end{array}$ \\
\hline 2 & From your observations, would you say that language has a bearing on their performance? \\
\hline 3 & $\begin{array}{l}\text { Briefly share the extent to which you see the interplay between language and identity as } \\
\text { they pertain specifically to this cohort. }\end{array}$ \\
\hline 4 & Can you cite a few instance where you saw this interplay and the concomitant implications? \\
\hline 5 & $\begin{array}{l}\text { From your experience, do you have any suggestions regarding how this situation can be } \\
\text { addressed in the academia? }\end{array}$ \\
\hline
\end{tabular}

\section{The data}

Below are tables with some of the data, as adapted from the study by Maseko (2015). Here, attention is specifically paid to the data pertaining to the argument made in this discussion. Three themes were derived, with two sub-categories each. The analyses followed immediately after the presentation of the data.

Table 1: Prior exposure in pre-university social contexts (Theme 1 and Category 1 )

\begin{tabular}{|c|c|c|}
\hline Theme 1 & Category 1 & C1 Data \\
\hline $\begin{array}{l}\text { Participants' use } \\
\text { of English in } \\
\text { pre-university } \\
\text { contexts }\end{array}$ & $\begin{array}{l}\text { Prior } \\
\text { exposure to } \\
\text { English in the } \\
\text { pre-university } \\
\text { social } \\
\text { context }\end{array}$ & $\begin{array}{l}\text { Y1s1: Well, I kinda used it everywhere. I don't have a } \\
\text { problem with English... I also used to read a lot... } \\
\text { Y2s2: I just used my Home Language everywhere .......the } \\
\text { background was local so everything was local... it's quite } \\
\text { difficult now. } \\
\text { Y3s3: There's no one who speaks English where I stay... } \\
\text { Y1s2: I only started speaking English when I came here } \\
\text { [and] it was very difficult...it's still difficult when I want to say } \\
\text { some words I still struggle because this is where I started } \\
\text { to speak English and to socialise with people who speak } \\
\text { English only... }\end{array}$ \\
\hline
\end{tabular}


Table 2: $\quad$ Prior exposure in pre-university school contexts (Theme 1 and Category 2)

\begin{tabular}{|c|c|c|}
\hline Theme 1 & Category 2 & C2 Data \\
\hline $\begin{array}{l}\text { Participants' use } \\
\text { of English in pre- } \\
\text { university school } \\
\text { contexts }\end{array}$ & $\begin{array}{l}\text { Prior exposure } \\
\text { to English } \\
\text { in the pre- } \\
\text { university } \\
\text { school context }\end{array}$ & $\begin{array}{l}\text { Y1s1: We were taught in English but sometimes it } \\
\text { was like...the teachers would use the languages we } \\
\text { were used to. } \\
\text { Y2s3: ...in some other classes we would be code } \\
\text { switching... } \\
\text { Y3s3: We didn't really get the chance to learn } \\
\text { English because during class English was not used } \\
\text { from the start of the lesson to the end...We were } \\
\text { not really exposed to English in a way that would } \\
\text { help us to understand it the way we're supposed to. } \\
\text { Y2s1: Home Language was used a lot of times... it } \\
\text { was mixed up } \\
\text { Y2s2: I would understand everything in my mother } \\
\text { tongue...you can't go anywhere without English }\end{array}$ \\
\hline
\end{tabular}

\section{Analysis of Tables 1 and 2}

The above tables are a reflection of the responses for the themes and categories. The varied responses reflected in the two categories of Theme 1 were largely indicative of limited exposure to English that would assist towards epistemological access - "...maybe I would use English once", "I can't say we learnt much English" in both social and pre-university school contexts. The data shows that prior exposure did not mitigate against the negative effects of the combination of codification, meritocracy and performativity, thus necessitating appropriate transformative mediation in this regard.

The responses from a second-year student served to partially confirm the claims about the discomfiture accruing from learnerism, when she struggled to express herself and subsequently requested to express herself in her home language. Other participants opined that a user-friendly tutor system would allow for the use of their home languages. One of the participants expressed the concern that a lack of proficiency in English and, by implication, limited familiarity with the codification system of the academia, would limit her chances of obtaining employment outside of the borders of South Africa. 
Table 3: Language in the university context (Theme 2 \& Category 1)

\begin{tabular}{|c|c|c|}
\hline Theme 2 & Category 1 & C1 Data \\
\hline $\begin{array}{l}\text { Language use in } \\
\text { the university }\end{array}$ & $\begin{array}{l}\text { English as the language of } \\
\text { learning and teaching in the } \\
\text { university context }\end{array}$ & $\begin{array}{l}\text { Y1s1: I wrote a test...found a word I } \\
\text { could not understand ...it was difficult... } \\
\text { sometimes just because we are at } \\
\text { university they seem to think that we know } \\
\text { everything...they just put something and } \\
\text { they expect us to be able to do it... } \\
\text { Y3s1: Obviously the lecturers have to } \\
\text { teach in English of which we are not used } \\
\text { to listen to English each and every time... } \\
\text { in my first year I found it so difficult... } \\
\text { Y1s1: We should like um ah...I don't know } \\
\text { what to say...Ya something should done... } \\
\text { well we're not the same...some people are } \\
\text { struggling... extremely... although there } \\
\text { are tutors but it's still not enough......they } \\
\text { just call something out and they just move } \\
\text { on so you are left with no idea of what } \\
\text { they are saying. } \\
\text { W1: The assumption is, and I refer to the } \\
\text { university in its entirety, that because you } \\
\text { speak English you can cope... We shout at } \\
\text { you because your essay is bad... } \\
\text { Y3s3: Um because the university uses } \\
\text { English...um...as a medium of instruction } \\
\text { we have to...have to...I don't know how to } \\
\text { say it...we have to... }\end{array}$ \\
\hline
\end{tabular}

Table 4: Language in the university context (Theme 2 \& Category 2)

\begin{tabular}{|c|c|c|}
\hline Theme 2 & Category 2 & C2 Data \\
\hline $\begin{array}{l}\text { Language in } \\
\text { the university } \\
\text { context }\end{array}$ & $\begin{array}{l}\text { General } \\
\text { language use } \\
\text { and support in } \\
\text { the university }\end{array}$ & $\begin{array}{l}\text { Y2s1: I would understand everything in my Home } \\
\text { Language...it would be an advantage, I'd clearly } \\
\text { understand things better...there wouldn't be any term } \\
\text { where I would say, here I'm stuck. } \\
\text { Y2s2: I've thought of that before like if we're allowed } \\
\text { to use our language as a medium of instruction for our } \\
\text { modules that it would have been better but again it's a } \\
\text { disadvantage because when you go further you have to } \\
\text { know English because it's the most used language that } \\
\text { we use outside and inside our country. } \\
\text { Y3s3: I had to adapt } \\
\text { B1: You know what, I think we just need to simplify } \\
\text { everything....and even the instructions we need to make } \\
\text { sure that they are simple and easy to be understood } \\
\text { and followed. }\end{array}$ \\
\hline
\end{tabular}




\section{Analysis of Tables 3 and 4}

The participants were requested to give an indication of the extent to which English, as the language of the academia, played a role in their academic performance. The responses by various participants confirmed the discomfort that is associated with McFarlane's (2013) notion of learnerism. The data further indicate that this uneasiness often resulted in a measure of reticence to participate, which had implications for their academic performance.

One of the lecturers tacitly supported the views presented by the students by pointing out that, "the assumption is that, because you speak English you can cope... we shout at you... but we don't put anything in place". Her colleague implicitly conceded with the views regarding the levels of difficulty and the resultant implications for performance - "You know what, I think we need to make language easier and simpler for them..." Her further observation was that "language creates a barrier which impacts on participation". This is a further confirmation of the need for an appropriate responsive strategy that would take into account these situational realities.

The data for Theme 2 reflected a slight ambivalence, which was simultaneously indicative of the paradox of language within this context. On the one hand, the participants indicated a preference for the use of the home language as an ideal situation. Yet, on the other hand, they expressed the reality that the meritocratic performativity-oriented context of the academia required that they demonstrate proficiency in English and familiarity with the code of knowledge reception and transmission with implications for academic performance.

Table 5: Identity factors in relation to participation and performance (Theme 3 \& Category 1 )

\begin{tabular}{|c|c|c|}
\hline Theme 3 & Category 1 & C2 Data \\
\hline $\begin{array}{l}\text { Identity factors } \\
\text { in relation to } \\
\text { participation and } \\
\text { performance }\end{array}$ & $\begin{array}{l}\text { Participants' } \\
\text { negative affective } \\
\text { experiences } \\
\text { pertaining to } \\
\text { participation }\end{array}$ & $\begin{array}{l}\text { Y1s1: Yoh! As a first year I don't wanna lie, I've } \\
\text { never expressed myself verbally because I'm } \\
\text { scared, I have fear that maybe I won't say the right } \\
\text { words. Um...it's kinda like intimidating because } \\
\text { you've got like Whites and they so English and } \\
\text { like...I can speak English but I don't think that l'd be } \\
\text { able to express myself in a lecture hall full of people } \\
\text { who've been doing English like their whole lives... } \\
\text { Y2s2: ...every time maybe the lecturer is asking } \\
\text { a question in class first I have to think of like how } \\
\text { should I construct my words before I raise hand } \\
\text { to speak... } \\
\text { B1: To be honest in terms of class participation they } \\
\text { don't participate at all. Others can participate but it's } \\
\text { very limited. Others don't participate at all unless } \\
\text { I call out their names and say [for example]: "you } \\
\text { haven't spoken to me in the last three months"... } \\
\text { B1: Participation in my class is mainly with white } \\
\text { students... Language creates a barrier which } \\
\text { impacts on participation, particularly in group } \\
\text { work. Some would want to express their ideas } \\
\text { in their Home Language and their frustration is } \\
\text { evident since it ultimately results in visible lack } \\
\text { of confidence... }\end{array}$ \\
\hline
\end{tabular}


Table 6: Identity factors in relation to participation and performance (Theme 3 \& Category 2)

\begin{tabular}{|c|c|c|}
\hline Theme 3 & Category 2 & C2 Data \\
\hline $\begin{array}{l}\text { Identity factors } \\
\text { in relation to } \\
\text { participation and } \\
\text { performance }\end{array}$ & $\begin{array}{l}\text { Category 2: } \\
\text { Participants' } \\
\text { positive affective } \\
\text { experiences } \\
\text { pertaining to } \\
\text { participation }\end{array}$ & $\begin{array}{l}\text { Y3s2: I think there's a huge difference there } \\
\text { because l've acquired a bit of English so it's quite } \\
\text { better than last year. } \\
\text { Y3s1: I do a lot of research ...I read book to try and } \\
\text { improve myself } \\
\text { Y2s2: As time goes on you meet friends with higher } \\
\text { grades then you have to ask: How are you doing } \\
\text { this...then that's where they told me you have } \\
\text { to understand the concepts so you can answer } \\
\text { the question } \\
\text { Y3s2: Ok now...she'll explain something and I have } \\
\text { to look at it in my own time so I can explain it to } \\
\text { myself [to see] what was she trying to say. } \\
\text { W1: I've certainly found the students far more } \\
\text { willing to engage... }\end{array}$ \\
\hline
\end{tabular}

\section{Analysis of Tables 5 and 6}

The data for Themes 3 and their associated categories relate to the aspect of identity in reference to the students' dispositions and values. McFarlane's (2013) view of soul craft bears reference here. In this theme, there is evidence of the interplay between language and identity, as they were conceptualised in the study. Category 1 of this theme reflects the participants' negative experiences with regard to class participation and the implicit power relations (Cummins, 2000; Mayes, 2010). Words such as "fear", "intimidation", "frustration" and "lack of confidence" attest to this. On the other hand, Category 2 of this theme provides glimpses of the students' ability to self-regulate and adapt in an attempt to overcome the implicit negative implications of the combination of codification, meritocracy and performativity. This theme thus juxtaposes the positive and negative experiences pertaining to performance with the intention to foreground the role of metacognitive abilities in overcoming the potentially debilitating mix of dominant practices. In the study, this was related to critical consciousness and emergent transformative praxis.

\section{Concluding comments}

The data that were gleaned from the study, upon which this discussion is based, corroborated the inherent assumptions about the concomitant effects of language and identity-related factors (Maseko, 2015; Cummins, 1996). In relation to the key question of the research, the data confirmed the implications of the convergence of language and identity and its implications for the academic performance of the black L2 FP B.Ed. pre-service teacher cohort. The intention of the aforementioned study was to make an emancipatory and transformative contribution towards the improvement of the quality of teacher education, as it pertains specifically to the black African B.Ed. cohort. In this regard, the focus was on the convergence of language and identity in relation to the cohort's academic performance.

A reinterpretation of the data in relation to this discussion points towards the fact that class-regulated and subjugated prior exposure does not assist towards overcoming the 
challenges associated with the negative effects of the combination of codification, meritocracy and performativity. The participants' responses were regarded as instructive in paving a responsive support strategy that would align with a decolonial transformative agenda. In general, their ideological orientation with regard to language was a reflection of the reality of the ramifications of the hegemony of English (Alexander, 2010).

This paper highlighted the negative effects of the combination of codification, meritocracy and performativity with the intention to contribute towards responsive transformative social justice support strategies. McGregor (2003: 52) presents the apt view that "teaching for social justice has a common goal of preparing teachers to recognise, name and combat inequality through relevant pedagogy". This brings to the fore the notion of critical consciousness, which in the study was associated with language, cognition and critical moral consciousness, as it is associated with ontological affective factors in this study. In view of this, it is recommended that students should be appropriately exposed to the culture and codification systems of the academia to equip them adequately to cope in align with a critical emancipatory and transformative agenda.

In summation, the data of the study corroborated the need for a response that would be cognisant of the assumptions made about the negative effects of the potentially debilitating combination of codification, meritocracy and performativity. This article is thus an attempt to contribute towards strengthening pre-service teacher preparation through emancipatory and transformative support systems that are designed to serve a multi-layered counter-hegemonic (and, by implication, decolonial) social justice purpose.

\section{References}

Akinbode, A. 2013. Teaching as lived experience: The value of exploring the hidden and emotional side of teaching through reflective narratives. Studying Teacher Education, 9(1), 62-73. https://doi.org/10.1080/17425964.2013.771574

Alexander, N. 2010. Schooling in and for the new South Africa. The Journal of the Helen Suzman Foundation. Focus on Learning and Teaching: Galvanizing Education, 56, 7-13.

Ayers, W. 2004. Teaching towards freedom: Moral commitment and ethical action in the classroom. Boston: Beacon Press.

Ball, S. 2003. The teacher's soul and the terrors of performativity. Journal of Education Policy, 18(2), 215-228. https://doi.org/10.1080/0268093022000043065

Ball, S. 2012. The making of a neo-liberal academic. Research in Secondary Education, 2(1), 29-31.

Bernstein, B. 1990. Class, codes and control: The structuring of pedagogic discourse. London and New York: Routledge. https://doi.org/10.4324/9780203011263

Bertram, C. \& Christiansen, I. 2014. Understanding research: An introduction to reading research, Pretoria: Van Schaik.

Bozalek, V., Carolissen, R., Leibowitz, B., Swartz L. \& Rohleder, P. 2010. Engaging with difference in Higher Education through collaborative inter-institutional pedagogical practices. South African Journal of Higher Education 24(6), 1023-1078.

Bourdieu, P. 1991. Language and symbolic power. Massachusetts/Cambridge: Harvard University Press. 
Christie, F. 2002. Classroom discourse analysis. Continuum. London.

Creswell, J.W. 2003. Research design: Qualitative and quantitative and mixed method approach. London: Sage.

Creswell, J.W. 2008. Educational research: Conducting and evaluating quantitative and qualitative research. New Jersey: Pearson Education.

Cummins, J. 1996. Negotiating identities: Education for empowerment in a diverse society. Los Angeles: California Association for Bilingual Education.

Cummins, J. 2000. Language, power and pedagogy: Bilingual children in the crossfire. Clevedon: Multilingual matters.

Denzin, N.K. \& Lincoln, Y.S. 2000. Handbook for qualitative research. Thousand Oaks, CA: Sage.

Fairclough N.L. 1992. Discourse and Social Change. Cambridge: Polity Press.

Fairclough, N.L. \& Wodak, R. 1997. Critical discourse analysis. In: T.A. van Dijk (Ed.). Discourse Studies. A multi-disciplinary introduction. Vol 2 Discourse as social interaction (pp. 258-284) London: Sage.

Fairclough, N. 2003. Analyzing Discourse Analysis for Social Research. New York: Routledge.

Freire, P. 1970. Pedagogy of the oppressed. London: Penguin.

Gatsheni-Ndlovu, S. 2015. Decoloniality in Africa: A continuing search for a new world order. ARAS. 36(2).22-50.

Gilham, B. 2000. The Research Interview. Continuum: London.

Holstein, J. \& Gubrium, J.1995. The active interview. Thousand Oaks: Sage. https://doi. org/10.4135/9781412986120

Kincheloe, J.L. 2008. Critical pedagogy primer, 2nd ed. New York: Peter Lang. https://doi. org/10.1007/978-1-4020-8224-5

Kincheloe, J.L. McLaren, P. \& Steinberg, S.R. 2007. Critical Pedagogy and Qualitative Research. In: N.K. Denzin \& Y.S. Lincoln (Eds.). Handbook of Qualitative research (pp. 685696). Thousand Oaks, CA: Sage.

Lawrence-Lightfoot, S. 2000. The art and science of portraiture. San Francisco: Jossey-Bass.

Ledwith, M. On being critical. Unititng theory and practice through emancipatory action research. Education Action Research. 15(4), 597-611. https://doi.org/10.1080/09650790701664021

Lister, R. 2006. Ladder of opportunity or engine of inequality? The Political Quarterly, 77(1), 232-236. https://doi.org/10.1111/j.1467-923X.2006.00799.x

Mahlomaholo, S. 2009. Critical emancipatory research and academic identity. Africa Education Review, 6(2), 224-237. https://doi.org/10.1080/18146620903274555

Maseko, N. 2015. Language and identity in the academic performance and portraiture of black BEd Foundation Phase students. Doctoral thesis. Pretoria: University of Pretoria.

Mayes, P. 2010. The discursive construction of identity and power in the critical classroom: Implications for applied critical theories. Discourse and Society, 21(2), 189-210. https://doi. org/10.1177/0957926509353846 
McFarlane, B. 2013. The surveillance of learning. A critical analysis of university attendance policies. Higher Education Quarterly, 67(4), 358-373. https://doi.org/10.1111/hequ.12016

McGregor, J. 2003. Making spaces: teacher workplace topologies. Pedagogy, Culture and Society, 11(3), 353-375. https://doi.org/10.1080/14681360300200179

McKenna, S. 2010. Cracking the code of academic literacy: An ideological task. In: C. Hutchings \& J. Garraway (Eds.). Beyond the university gates, provision of extended curriculum programmes in South Africa. Proceedings of the January 2009 Rhodes University Foundation Seminar, Rhodes University.

McNamee, S.J. \& Miller, Jr. R.K. 2004. The meritocracy myth. North Carolina: Rowan and Littlefield.

Merten, D.M. 2005. Research methods in education and psychology: Integrating diversity with quantitative and qualitative approaches. 2nd ed. Thousand Oaks: Sage.

Mertens, D.M. 2009. Transformative research and evaluation. New York: The Guild Press.

Mertens, D.M. 2010. Research and evaluation in education and psychology. Thousand Oaks, CA: Sage

Mezirow, J. 2000. Learning as transformation: Critical perspectives on a theory in progress. San Francisco: Jossey Bass.

Padgett, D.K. 1998. Qualitative methods in social work research. Challenges and rewards. Thousand Oaks, CA: Sage.

Patton, M.Q. 2002. Qualitative research and evaluation methods. Thousand Oaks, CA: Sage.

Rall, J.D. 2002. Critical consciousness, critical thinking and academic composition. Peer review workshop. College Course Shell.

Young, N. 2006. The Rise of the Meritocracy. New Brunswick: Transaction Publishers.

Van Dijk,T. 2008. Media(ted) discourse and society, rethinking the framework of critical discourse analysis. Journalism Studies, 9(2),161-177.https://doi.org/10.1080/14616700701848162 